\title{
FACTORS DETERMINING THE SUSCEPTIBILITY OF MICE TO EXPERIMENTAL PHYCOMYCOSIS
}

\author{
M. J. CoRbel AND SusAn M. EADES \\ Ministry of Agriculture, Fisheries and Food, Central Veterinary Laboratories, \\ Weybridge, Surrey

\section{Plates XLVII-XLIX}

SEVERAL species of normally saprophytic phycomycetes are recognised as opportunist pathogens of man and domestic animals (Ainsworth and Austwick, 1959; Baker, 1971). In most instances the fungal infection is secondary to a recognisable predisposing condition. However, in mycotic abortion of cattle, in which various mucoraceous and other types of fungi have been implicated (Ainsworth and Austwick, 1959), no predisposing factor has been identified although placental invasion may be promoted by fungal growth-stimulants present in the foetal cotyledon tissue (Corbel and Eades, 1973; Eades and Corbel, 1973). In many cases Absidia ramosa (A. corymbifera) is the only organism implicated in the infection.

A. ramosa and other phycomycetes also occasionally produce extra-placental mycotic lesions in young or adult animals of various species. As in the case of bovine mycotic abortion, these infections are sporadic with the majority of animals exposed to natural infection having a high degree of resistance. The nature of this resistance and the reasons for its apparent failure in those animals developing active infection are as yet undetermined.

In the present study an attempt has been made to characterise some of the factors that determine susceptibility and resistance to phycomycotic infection. Experimentally produced $A$. ramosa infection in mice has been used as a model for examining these. This test system was selected because mice are susceptible to both natural and experimental infection with $A$. ramosa (Symeonidis and Emmons, 1955; Smith and Jones, 1973).

\section{MATERIALS AND METHODS}

Mice

Specific pathogen-free male and female $\mathrm{C} 3 \mathrm{H}$ mice obtained from Scientific Agribusiness Consultants (International) Ltd, Braintree, Essex, were used. They were caged in groups of five or six animals and allowed free access to water and a standard pelleted mouse diet. All mice were between 19 and 22 days old and weighed between 10 and $12 \mathrm{~g}$ at the beginning of the experiment.

\section{Fungal strains}

The strains of $A$. ramosa used were from the fungal culture collection kept at this laboratory. Strain no. V73/8 was used for most of the current work and was a recent isolate from 
the stomach contents of an aborted bovine foetus. The other strains used had been isolated over a number of years. All isolates were preserved by lyophilisation, although some had been maintained by serial subculture before this.

Strain V6473A was isolated from bovine abortion material, strain V4715 from a phycomycotic abomasal ulcer, strain V283 from bovine urine and strain V73/247/8 from a feed sample.

Except where stated otherwise, all inoculations were performed with strain V73/8.

\section{Preparation of inoculum}

Reconstituted lyophilised cultures were grown on $2 \%(\mathrm{w} / \mathrm{v})$ malt-extract agar plates, checked for purity and subcultured on malt-extract agar slopes. These were incubated aerobically at $37^{\circ} \mathrm{C}$ for 3 days and the spores harvested by addition of phosphate-buffered saline (PBS: $0.15 \mathrm{M} \mathrm{NaCl}, 0.01 \mathrm{M}$ phosphate buffer, $p \mathrm{H} \mathrm{7.4)}$ and shaking with glass beads. Large particles were allowed to sediment under gravity and the supernatant spore suspension was decanted. The total number of spores in unit volumes was determined by direct counting in a Neubauer chamber. The concentration of viable units was determined by plating serial 10 -fold dilutions of suspensions on to malt-extract agar and counting the number of $A$. ramosa colonies produced after incubation for $2-3$ days at $37^{\circ} \mathrm{C}$.

Suspensions for inoculation were prepared by dilution from the concentrated stock suspensions and kept at $4^{\circ} \mathrm{C}$ until required. All were used within $4 \mathrm{~h}$ of preparation. These suspensions contained a small proportion of hyphal fragments which were almost certainly non-viable.

With the exception of $A$. ramosa strain V283 which produced a low proportion of viable spores, equivalent to $20-25 \%$ of the total count, the viability of the spore preparations used was at least $90 \%$ of the total count. For A. ramosa strain V73/8, usually at least $95 \%$ of the spores were viable and except where stated to the contrary the viable count was treated as equivalent to the total count.

\section{Mouse inoculation}

The mice were inoculated by the intravenous, subcutaneous, intraperitoneal or intracerebral routes by means of disposable syringes and $13 \mathrm{~mm} \times 27 \mathrm{G}$ needles. Volumes of inoculum used were $0.1 \mathrm{ml}$ for intravenous inoculation and $0.2 \mathrm{ml}$ for subcutaneous and intraperitoneal inoculation. Intracerebral inoculations were done by injecting $0.025 \mathrm{ml}$ volumes of suspension into the left cerebral hemisphere.

All inoculated animals were inspected at least once daily for signs of disease and those showing evidence of disturbance were kept under more frequent surveillance.

\section{Post-mortem examination}

Necropsies were performed as soon after death as possible. The animals were examined for external signs of disease or injury before opening the abdominal, thoracic and cranial cavities. After visual inspection of the internal organs, these were removed aseptically and divided into two portions. One portion of fresh tissue was reserved for microscopical and cultural examination for fungi, the second portion was fixed in $10 \%$ buffered formalin and kept for histopathological examination.

Mycological examination was done by direct microscopy of fresh tissue samples mounted in $40 \%(\mathrm{w} / \mathrm{v})$ aqueous $\mathrm{KOH}$. The specimens were examined in a Leitz Ortholux microscope with interference phase-contrast optics.

Samples were cultured for fungi by plating tissue homogenates on to $2 \%$ malt-extract agar containing 20 units of benzylpenicillin and $40 \mu \mathrm{g}$ of streptomycin per ml. The plates were incubated aerobically at $37^{\circ} \mathrm{C}$ and inspected daily for fungal growth. Fungal isolates were identified on the basis of their morphological characteristics.

Histopathological examinations were made on paraffin-embedded sections of formalinfixed tissue stained with haematoxylin and eosin, or by the periodic acid-Schiff method 
(PAS) with light green counterstain (Emmons, Binford and Utz, 1970). Some sections of brain tissue were also stained by the Weil-Davenport technique (Culling, 1974).

\section{Examination of blood and urine samples}

Blood samples were collected either from the tail vein or, if larger quantities were required, by exsanguination from the pulmonary artery under ether anaesthesia. Total leucocyte counts were determined manually with a Hawskley-Thoma counting chamber. Differential leucocyte counts were performed on fresh blood films stained with Wright's stain at $p \mathbf{H ~ 6 . 8 . ~}$ Blood-urea concentrations were determined by the urease method according to Henry (1964).

Urine samples were collected as fresh specimens voided on to clean polythene sheets. The $p \mathrm{H}$ and the glucose, haemoglobin and protein contents were assessed by means of Hemacombistix test strips (Ames Company, Slough).

\section{Immunosuppressive treatment}

To investigate the role of various immune mechanisms in conferring natural resistance to fungal infection, mice were treated with various immunosuppressive agents before the inoculation of $A$. ramosa spores.

Cyclophosphamide (Ward Blenkinsop, London) was freshly dissolved in pyrogen-free water and given by intraperitoneal injection at the rate of $100 \mathrm{mg}$ per $\mathrm{kg} 24 \mathrm{~h}$ before the intravenous inoculation of $5 \times 10^{4}$ or $5 \times 10^{5}$ spores of $A$. ramosa. Similar doses of spores were used to challenge the mice subjected to all of the immunosuppressive regimes.

Azathioprine (Burroughs Wellcome, London) freshly dissolved in pyrogen-free water was injected intraperitoneally in doses of $15 \mathrm{mg}$ per $\mathrm{kg}$ on the day before inoculation, followed by daily doses of $5 \mathrm{mg}$ per $\mathrm{kg}$ for 5 successive days.

Horse anti-mouse lymphocyte serum (ALS; batch no. K6204; Wellcome Reagents Ltd, Beckenham) was given as three separate subcutaneous injections of $0.5 \mathrm{ml}$ on the day before inoculation, on the day of inoculation and on the following day.

Cortisone acetate (British Drug Houses, Poole) in doses of $5 \mathrm{mg}$ of steroid emulsified in $1 \%(\mathrm{v} / \mathrm{v})$ Tween 20 in PBS, was injected by the subcutaneous route at the time of inoculation. A similar dose was given on the day after inoculation.

Zymosan (Sigma, London) suspended in PBS was injected in doses of $10 \mathrm{mg}$ by the subcutaneous route at the time of inoculation.

Heat-aggregated $\gamma$-globulin (HAGG), prepared as described by Timoney (1970), was injected in 3-mg doses at the time of inoculation.

Iron. The effect of $\mathrm{Fe}$ (II) ions on susceptibility was assessed by suspending the inoculum of $5 \times 10^{5}$ or $5 \times 10^{6} \mathrm{~A}$. ramosa spores in $0.25 \mathrm{-ml}$ volumes of freshly prepared $0.002 \mathrm{M}$ ferrous ammonium sulphate and injecting this by the intravenous route.

Reticuloendothelial blockade was produced by injecting $0.5 \mathrm{ml}$ of colloidal carbon (Pelikan Ink; Gurr, London), or $0.4 \mathrm{ml}$ of $25 \%(\mathrm{w} / \mathrm{v})$ thorium dioxide, by the intraperitoneal route c. $24 \mathrm{~h}$ before challenge.

Blood samples were collected from untreated control animals and from uninoculated mice undergoing immunosuppressive treatment, before treatment began and on the eighth day after the beginning of treatment.

\section{RESULTS}

\section{The effect of inoculation with A. ramosa spores}

After intravenous injection of graded doses of spores from $A$. ramosa strain $\mathrm{V} 73 / 8$, no signs of disturbance became evident in any of the mice until c. $48 \mathrm{~h}$ after inoculation. At about this time a proportion of the mice receiving large doses of spores, corresponding to $5 \times 10^{5}$ or $5 \times 10^{6}$ viable units, began to show 
signs of disease. Initially, the affected animals showed reduced mobility, ruffled fur and shivering. Unless deliberately disturbed they sat in a hunched position with partially closed eyes. This state lasted for a variable period, usually between 4 and $8 \mathrm{~h}$. Subsequently the condition of the animals deteriorated and this was marked by development of a continuous circling movement. At this stage the animals showed reduced responsiveness to external stimuli but retained their righting reflexes. Some of the animals subsequently developed convulsions followed rapidly by death, others collapsed and died apparently from exhaustion. In all cases death occurred within $12 \mathrm{~h}$ of the onset of signs of disease.

An essentially similar clinical state developed in varying proportions of the animals receiving smaller doses of spores. In these the time of onset of clinical disease varied from 2 to 7 days, with most cases occurring between 3 and 5 days after inoculation. No deaths occurred in animals surviving more than 8 days after inoculation, even though some were observed for up to 3 months. The proportion of animals developing the disease was related to the dose of spores inoculated (table I). Thus animals receiving spore doses of up to 500 viable units did not develop lethal disease. Occasional deaths, preceded by development of typical clinical signs, occurred in animals receiving doses of $5 \times 10^{3}$ viable spores. The proportion of infected animals increased with increasing spore dose. Doses of between $5 \times 10^{5}$ and $5 \times 10^{6}$ viable units produced lethal infection in about $50 \%$ of the animals. Doses of $5 \times 10^{7}$ spores killed between 90 and $100 \%$ of the animals within 7-8 days. Irrespective of the dose, the clinical and pathological features of the disease were always the same, the only difference being in the more rapid rate of onset of clinical disease in the groups receiving higher doses. Nevertheless, a minimum incubation period of $40-48 \mathrm{~h}$ was required for even the largest doses. Post-mortem examination of the animals dying with the characteristic signs of the disease failed to show gross

TABLE I

The response of mice to intravenous inoculation of graded doses of spores from Absidia ramosa strain $V 73 / 8$

\begin{tabular}{|c|c|c|c|c|c|c|c|c|c|c|c|c|c|}
\hline \multirow{3}{*}{$\begin{array}{l}\text { Number of } \\
\text { viable } \\
\text { spores } \\
\text { injected }\end{array}$} & \multirow{3}{*}{$\begin{array}{l}\text { Number of } \\
\text { deaths* }\end{array}$} & \multicolumn{12}{|c|}{ Number of animals with infection detectable by } \\
\hline & & \multicolumn{6}{|c|}{ microscopy $\dagger$ in } & \multicolumn{6}{|c|}{ culture in } \\
\hline & & liver & lung & spleer & idne & brain & heart & liver & lung & spleer & kidne & brain & heart \\
\hline $\begin{array}{c}5 \times 10^{7} \\
5 \times 10^{6} \\
5 \times 10^{5} \\
5 \times 10^{4} \\
5 \times 10^{3} \\
5 \times 10^{2} \\
50\end{array}$ & $\begin{array}{l}6 \\
5 \\
1 \\
1 \\
1 \\
0 \\
0\end{array}$ & $\begin{array}{l}0 \\
0 \\
0 \\
0 \\
0 \\
0 \\
0\end{array}$ & $\begin{array}{l}0 \\
0 \\
0 \\
0 \\
0 \\
0 \\
0\end{array}$ & $\begin{array}{l}0 \\
0 \\
0 \\
0 \\
0 \\
0 \\
0\end{array}$ & $\begin{array}{l}6 \\
5 \\
1 \\
1 \\
0 \\
0 \\
0\end{array}$ & $\begin{array}{l}6 \\
5 \\
1 \\
0 \\
1 \\
0 \\
0\end{array}$ & $\begin{array}{l}\mathbf{0} \\
0 \\
0 \\
0 \\
0 \\
0 \\
0\end{array}$ & $\begin{array}{l}6 \\
6 \\
6 \\
5 \\
3 \\
0 \\
0\end{array}$ & $\begin{array}{l}4 \\
5 \\
4 \\
1 \\
0 \\
0 \\
0\end{array}$ & $\begin{array}{l}6 \\
6 \\
6 \\
5 \\
3 \\
0 \\
0\end{array}$ & $\begin{array}{l}5 \\
6 \\
3 \\
3 \\
0 \\
0 \\
0\end{array}$ & $\begin{array}{l}4 \\
4 \\
0 \\
0 \\
0 \\
0 \\
0\end{array}$ & $\begin{array}{l}0 \\
0 \\
0 \\
0 \\
0 \\
0 \\
0\end{array}$ \\
\hline
\end{tabular}

* Six mice in each group.

$\dagger$ Examination of KOH-digested specimens for fungal hyphae. 
lesions in any of the organs. Microscopic examination of crushed tissues mounted in $\mathrm{KOH}$ revealed non-septate fungal hyphae in the brain and kidneys of most animals. Hyphae were not detected in any other organ. Fungal spores were not detected microscopically in $\mathrm{KOH}$ preparations of any of the tissues, but cultural examination showed that they were invariably present in large numbers in the liver, spleen, kidneys and lungs. A. ramosa was usually although not invariably cultured from the brains of animals in which hyphae could be demonstrated microscopically (table I).

Histological examination of tissue sections stained with haematoxylin and eosin failed to reveal specific lesions in any organs except the brain and kidneys. In the brain, the lesions consisted of clusters of microglial cells interspersed with small numbers of polymorphonuclear leucocytes surrounding developing fungal hyphae of typical mucoraceous type (figs. 1 and 2). Although visible in sections stained with haematoxylin and eosin (fig. 3) the hyphae were more easily seen in PAS-stained preparations (fig. 4). Frequently fragments of mycelium could be seen that were not associated with any cellular reaction (fig. 3). This was particularly common in animals dying soon after inoculation. Lesions were not restricted to any particular part of the brain although they were most frequent in the tissue surrounding the third ventricle and the cerebral aqueduct. Lesions or fungal hyphae were not observed in the cerebellum and rarely in the cerebral cortex. Because the hyphae developing from single spores tended to ramify for considerable distances through the brain substance, as seen in $\mathrm{KOH}$ or lactophenol preparations (fig. 5), the small, apparently localised, lesions visible in histological sections did not adequately represent the full extent of the damage resulting from $A$. ramosa infection.

In the kidneys, the lesions were usually larger and more circumscribed than those encountered in the brain. They were most frequent in the lower part of the medulla and in the papilla and pelvis of the kidney. The lesions consisted of clumps of fungal mycelium composed of non-septate hyphae and surrounded by a cellular infiltrate consisting predominantly of histiocytes interspersed with smaller numbers of neutrophil granulocytes (fig. 6). Lymphocytes were rarely present and multinucleate giant cells were never seen in these acute lesions. Although extensive destruction of tubular elements was evident at the site of fungal growth, the tissue immediately adjacent to the lesions was apparently healthy.

Hyphae and gross or microscopic lesions were not observed in the liver, lungs, spleen, brain, heart or adrenal tissues of the inoculated mice which failed to develop frank signs of disease. However, typical localised lesions containing mycelium were present in the kidneys of a proportion of these animals.

Examination of the urine of inoculated mice developing lethal infection failed to reveal the presence of blood or glucose. The protein concentrations and $\mathrm{pH}$ were also within the normal range for mouse urine. Estimation of the blood-urea concentrations of mice in the terminal stages of infection indicated moderate to severe uraemia with plasma-urea concentrations ranging from 140 to $260 \mathrm{mg}$ per $100 \mathrm{ml}$. However, the plasma urea concentrations of mice 
killed soon after the onset of signs of cerebral infection were much lower, ranging from 70 to $120 \mathrm{mg}$ per $100 \mathrm{ml}$.

\section{Effect of route of inoculation}

Intracerebral inoculation of $A$. ramosa spores was much more effective in establishing infection than inoculation by the intravenous route. Thus, lethal infection developed in animals of all groups receiving probable spore doses ranging from a single viable unit up to $2 \times 10^{6}$ viable units, the highest dose tested. The onset of infection was earliest in the groups receiving the higher doses, signs of disease appearing from $36 \mathrm{~h}$ after inoculation. In animals receiving low doses, signs of disease did not usually appear until 5 or 6 days after inoculation. The clinical and pathological features of the disease were essentially similar to those following intravenous inoculation. Fungal hyphae could invariably be demonstrated in the brain by microscopic examination and $A$. ramosa could also be isolated in cultures of this. On histological examination, the lesions in the brain were similar to those resulting from intravenous inoculation but were usually much more extensive, consisting of dense accumulations of microglial cells surrounding developing hyphae at the site of inoculation in the left cerebral hemisphere (fig. 7). In some cases fungal hyphae appeared to penetrate the walls of cerebral blood vessels (fig. 8).

Unexpectedly, fungal hyphae were also sometimes present in the tissues of other organs and $A$. ramosa could be cultured from these. Thus, in three mice dying after intracerebral inoculation, mucoraceous hyphae were present in the kidneys as well as the brain. Hyphal fragments were also detected in the spleen of one of these animals and in the lungs of another. A. ramosa could be isolated in cultures of these organs but not from other tissues. Nevertheless, it is not certain that the hyphae observed were actively growing at the extracerebral sites. It is possible that they were simply metastatic fragments released into the blood from brain lesions and retained in the kidneys, lungs and spleen.

Other routes of inoculation were much less effective in establishing infection. Thus no signs of systemic infection developed after subcutaneous injection of spores and $A$. ramosa was not detected in the tissues of these animals at necropsy. Similarly, no signs of infection were produced after intranasal or oral administration of up to $10^{9}$ viable spores. A. ramosa was, however, isolated from the lungs of one mouse killed between 2 and 3 days after intranasal inoculation.

After intraperitoneal injection of $A$. ramosa spores, most animals remained healthy. However, typical signs of cerebral infection followed by death were observed in one mouse inoculated by this route. At necropsy, non-septate hyphae were present in the brain, kidneys and liver and also in the peritoneal exudate. A. ramosa was cultured from these sources and also from the spleen. The histological appearances were similar to those observed in infections resulting from intravenous inoculation. Post-mortem examination of the remaining mice in this group failed to reveal any fungal hyphae or any lesions. A. ramosa was nevertheless isolated on culturing the liver and spleen of most of these animals. 
The effect of age and sex on susceptibility to A. ramosa

The susceptibility of the mice to intravenous challenge with $A$. ramosa decreased with increasing age (table II). Thus, mice 10-12 weeks old required doses of $5 \times 10^{7}$ spores to produce a death rate comparable with that given by between $5 \times 10^{5}$ and $5 \times 10^{6}$ spores in mice 3 weeks old. A similar effect was seen after inoculation by the intracerebral route. In this case, doses of 500 spores killed between 50 and $60 \%$ of 3-month-old mice whereas doses of five spores killed $100 \%$ of the younger mice. Although slight differences were noted in individual experiments, no consistent difference was observed in the susceptibility of male and female animals to lethal infection by $A$. ramosa in trials involving more than 700 mice (unpublished observations).

\section{The effect of source of fungal strain on pathogenicity}

Comparison of the effects of intravenous inoculation of $A$. ramosa strains isolated from various pathological sources and from the environment failed to reveal any fundamental differences. All of the strains produced lethal infection with typical cerebral signs in a similar proportion of animals given doses of between $5 \times 10^{5}$ and $5 \times 10^{6}$ viable spores. One strain, V283, which has been maintained in the laboratory for many years, tended to produce spore preparations of low viability and thus larger total spore doses were needed to produce lethal infection. The clinical, pathological and mycological features of the disease produced by each strain were similar to those produced by strain V73/8.

\section{TABLE II}

The effect of age on susceptibility to intravenous and intracerebral inoculation of spores from Absidia ramosa strain $V 73 / 8$

\begin{tabular}{|c|c|c|c|c|c|c|c|}
\hline \multirow{2}{*}{$\begin{array}{l}\text { Age of mice } \\
\text { (days) }\end{array}$} & \multirow{2}{*}{$\begin{array}{l}\text { Number of } \\
\text { viable } \\
\text { spores } \\
\text { injected }\end{array}$} & \multirow{2}{*}{$\begin{array}{l}\text { Route of } \\
\text { inoculation }\end{array}$} & \multirow{2}{*}{$\underset{\text { deaths* }}{\text { Number of }}$} & \multirow{2}{*}{$\begin{array}{l}\text { Number } \\
\text { examined } \\
\text { micro- } \\
\text { scopically }\end{array}$} & \multicolumn{3}{|c|}{ Number with hyphae in } \\
\hline & & & & & brain & kidney & $\begin{array}{l}\text { other } \\
\text { organs }\end{array}$ \\
\hline $18-21$ & $\begin{array}{c}5 \times 10^{7} \\
5 \times 10^{6} \\
250\end{array}$ & $\begin{array}{l}\text { intravenous } \\
\text { intravenous } \\
\text { intracerebral }\end{array}$ & $\begin{array}{l}6 \\
5 \\
6\end{array}$ & $\begin{array}{l}6 \\
5 \\
6\end{array}$ & $\begin{array}{l}6 \\
5 \\
6\end{array}$ & $\begin{array}{l}6 \\
5 \\
0\end{array}$ & $\begin{array}{l}0 \\
0 \\
0\end{array}$ \\
\hline $30-33$ & $\begin{array}{c}5 \times 10^{7} \\
5 \times 10^{6} \\
250\end{array}$ & $\begin{array}{l}\text { intravenous } \\
\text { intravenous } \\
\text { intracerebral }\end{array}$ & $\begin{array}{l}4 \\
2 \\
2\end{array}$ & $\begin{array}{l}6 \\
6 \\
6\end{array}$ & $\begin{array}{l}4 \\
1 \\
6\end{array}$ & $\begin{array}{l}5 \\
3 \\
0\end{array}$ & $\begin{array}{l}0 \\
0 \\
0\end{array}$ \\
\hline $42-45$ & $\begin{array}{c}5 \times 10^{7} \\
5 \times 10^{6} \\
250\end{array}$ & $\begin{array}{l}\text { intravenous } \\
\text { intravenous } \\
\text { intracerebral }\end{array}$ & $\begin{array}{l}4 \\
2 \\
1\end{array}$ & $\begin{array}{l}6 \\
6 \\
6\end{array}$ & $\begin{array}{l}4 \\
4 \\
4\end{array}$ & $\begin{array}{l}5 \\
5 \\
0\end{array}$ & $\begin{array}{l}0 \\
0 \\
0\end{array}$ \\
\hline $90-100$ & $\begin{array}{c}5 \times 10^{7} \\
250\end{array}$ & $\begin{array}{l}\text { intravenous } \\
\text { intracerebral }\end{array}$ & $\begin{array}{l}3 \\
1\end{array}$ & $\begin{array}{l}6 \\
6\end{array}$ & $\begin{array}{l}3 \\
1\end{array}$ & $\begin{array}{l}5 \\
0\end{array}$ & $\begin{array}{l}\mathbf{0} \\
0\end{array}$ \\
\hline
\end{tabular}

* Six mice in each group. 


\section{Effect of immunosuppressive agents on resistance to A. ramosa infection}

Treatment of mice with cyclophosphamide, azathioprine or ALS, although producing haematological evidence of lymphocyte depletion (table III) did not increase susceptibility to lethal infection with $A$. ramosa. Thus the numbers of deaths in the treated and control groups were the same (table IV). The distribution of fungal hyphae and spores in the treated animals was also similar to that in untreated animals.

Injection of HAGG, which produced complement depletion, definitely increased susceptibility to infection as indicated by an increase in the number of mice dying after inoculation. Zymosan, which depletes serum complement and also properdin, produced a similar increase in susceptibility. The characteristics of the disease produced in zymosan- and HAGG-treated mice were similar to those seen in untreated control animals except that two of the zymosan-treated mice had mucoraceous hyphae in the liver as well as in the kidneys and brain. Injection of $A$. ramosa spores suspended in a solution containing $\mathrm{Fe}(\mathrm{II})$ ions markedly increased the numbers of animals developing lethal infection. The characteristics of the disease produced were similar to those seen in untreated animals except that the microscopically visible fungal growth was confined to the brain and no kidney lesions were observed in the group treated with iron. Reticuloendothelial blockade with colloidal carbon or thorium dioxide also increased susceptibility to infection, lesions being confined predominantly to the brain.

Administration of cortisone acetate markedly increased the susceptibility of mice to $A$. ramosa infection. It also promoted active growth of the fungus in organs other than the brain and kidneys. The lesions in the cortisone-treated mice were characterised by a reduced or absent cellular reaction to the fungal

TABLE III

The effect of immunosuppressive treatments on the total and differential leucocyte counts of $\mathrm{C} 3 \mathrm{H}$ mice

\begin{tabular}{|c|c|c|c|c|c|c|}
\hline \multirow{2}{*}{$\begin{array}{c}\text { Immunosuppressive } \\
\text { agent }\end{array}$} & \multicolumn{5}{|c|}{ Differential leucocyte count ${ }^{*}$ : percentage of } & \multirow{2}{*}{$\begin{array}{l}\text { Total leucocyte } \\
\text { count } \dagger \text { per } \mathrm{mm}^{3}\end{array}$} \\
\hline & neutrophils & lymphocytes & monocytes & eosinophils & basophils & \\
\hline $\begin{array}{l}\text { Anti-lymphocyte } \\
\text { serum } \\
\text { Azathioprine } \\
\text { Cortisone acetate } \\
\text { Cyclophosphamide } \\
\text { Fe(II) SO } 4 \\
\text { HAGG } \$ \\
\text { Zymosan } \\
\text { None }\end{array}$ & $\begin{array}{c}76 \\
43 \\
N C \ddagger \\
37 \\
78 \\
44 \\
9 \\
22\end{array}$ & $\begin{array}{l}16 \\
50 \\
\text { NC } \\
60 \\
22 \\
52 \\
81 \\
66\end{array}$ & $\begin{array}{r}8 \\
6 \\
\text { NC } \\
1 \\
0 \\
3 \\
10 \\
1\end{array}$ & $\begin{array}{c}0 \\
2 \\
\text { NC } \\
2 \\
0 \\
1 \\
0 \\
1\end{array}$ & $\begin{array}{c}0 \\
0 \\
\text { NC } \\
0 \\
0 \\
0 \\
0 \\
0\end{array}$ & $\begin{array}{r}2,000-4,000 \\
10,000-13,000 \\
<2,000 \\
8,000-13,000 \\
12,000-16,000 \\
8,000-12,000 \\
6,000-8,000 \\
10,000-13,000\end{array}$ \\
\hline
\end{tabular}

- Three animals from each group were sampled. The figures given are the mean values.

$\dagger$ Range of values obtained.

$¥ \mathrm{NC}=$ numbers too low for valid count.

$\S \mathrm{HAGG}=$ heat-aggregated $\gamma$-globulin. 
hyphae. In some animals, focal necrotic lesions developed in the liver. These were of a type often associated with ischaemic necrosis and might have resulted from thrombosis of hepatic blood vessels by fungal hyphae. Direct evidence of this was not seen in the sections examined, although intravascular hyphae were seen in other preparations (fig. 8).

\section{Discussion}

The clinical characteristics of the disease resulting from parenteral inoculation of $A$. ramosa spores were consistent with severe infection of the central nervous system. This was substantiated by the post-mortem findings and by the failure to demonstrate active fungal growth in any organ other than the brain or kidneys. The clinical signs, the rapid onset and evolution of the disease and the presence of lesions and extensive fungal growth in the brain all suggested that invasion of the central nervous system was the primary cause of death. The

TABLE IV

The effect of treatment with immunosuppresssive agents on the susceptibility of mice to intravenous inoculation of spores from $A$. ramosa strain $V 78 / 3$

\begin{tabular}{|c|c|c|c|c|c|c|c|}
\hline \multirow{2}{*}{$\begin{array}{l}\text { Immunosuppressive } \\
\text { agent }\end{array}$} & \multirow{2}{*}{$\begin{array}{c}\text { Dose of } \\
\text { viable spores }\end{array}$} & \multirow{2}{*}{$\begin{array}{c}\text { Number of } \\
\text { deaths* }\end{array}$} & \multicolumn{5}{|c|}{$\begin{array}{c}\text { Number of mice with microscopic evidence of } \\
\text { A. ramosa infection in }\end{array}$} \\
\hline & & & liver & lung & spleen & kidney & brain \\
\hline Anti-lymphocyte serum & $\begin{array}{l}10^{5} \\
10^{4}\end{array}$ & $\begin{array}{l}2 \\
0\end{array}$ & $\begin{array}{l}\mathbf{0} \\
\mathbf{0}\end{array}$ & $\begin{array}{l}0 \\
0\end{array}$ & $\begin{array}{l}\mathbf{0} \\
\mathbf{0}\end{array}$ & $\underset{3}{\mathrm{ND} \dagger}$ & $\underset{3}{\text { ND }}$ \\
\hline Azathioprine & $\begin{array}{l}10^{5} \\
10^{4}\end{array}$ & $\begin{array}{l}2 \\
0\end{array}$ & $\begin{array}{l}\mathbf{0} \\
\mathbf{0}\end{array}$ & $\begin{array}{l}0 \\
0\end{array}$ & $\begin{array}{l}\mathbf{0} \\
\mathbf{0}\end{array}$ & $\underset{3}{\text { ND }}$ & $\underset{0}{\mathrm{ND}}$ \\
\hline Cortisone acetate & $\begin{array}{l}10^{5} \\
10^{4}\end{array}$ & $\begin{array}{l}5 \\
4\end{array}$ & $\begin{array}{l}1 \\
1\end{array}$ & $\begin{array}{l}2 \\
0\end{array}$ & $\begin{array}{l}1 \\
0\end{array}$ & $\begin{array}{l}2 \\
2\end{array}$ & $\begin{array}{l}5 \\
3\end{array}$ \\
\hline Cyclophosphamide & $\begin{array}{l}10^{5} \\
10^{4}\end{array}$ & $\begin{array}{l}2 \\
0\end{array}$ & $\begin{array}{l}\mathbf{0} \\
\mathbf{0}\end{array}$ & $\begin{array}{l}0 \\
0\end{array}$ & $\begin{array}{l}\mathbf{0} \\
\mathbf{0}\end{array}$ & $\begin{array}{l}2 \\
0\end{array}$ & $\begin{array}{l}2 \\
0\end{array}$ \\
\hline $\mathrm{Fe}$ (II) $\mathrm{SO}_{4}$ & $\begin{array}{l}10^{5} \\
10^{4}\end{array}$ & $\begin{array}{l}3 \\
4\end{array}$ & $\begin{array}{l}\mathbf{0} \\
\mathbf{0}\end{array}$ & $\begin{array}{l}\mathbf{0} \\
\mathbf{0}\end{array}$ & $\begin{array}{l}\mathbf{0} \\
\mathbf{0}\end{array}$ & $\begin{array}{l}\mathbf{0} \\
\mathbf{0}\end{array}$ & $\begin{array}{l}3 \\
4\end{array}$ \\
\hline HAGG & $\begin{array}{l}10^{5} \\
10^{4}\end{array}$ & $\begin{array}{l}5 \\
0\end{array}$ & $\begin{array}{l}0 \\
0\end{array}$ & $\begin{array}{l}\mathbf{0} \\
\mathbf{0}\end{array}$ & $\begin{array}{l}0 \\
0\end{array}$ & $\begin{array}{l}2 \\
0\end{array}$ & $\begin{array}{l}5 \\
0\end{array}$ \\
\hline $\begin{array}{l}\text { Reticuloendothelial } \\
\text { blockadef }\end{array}$ & $\begin{array}{l}10^{5} \\
10^{4}\end{array}$ & $\begin{array}{l}4 \\
4\end{array}$ & $\begin{array}{l}0 \\
0\end{array}$ & $\begin{array}{l}\mathbf{0} \\
\mathbf{0}\end{array}$ & $\begin{array}{l}0 \\
0\end{array}$ & $\begin{array}{l}0 \\
0\end{array}$ & $\begin{array}{l}4 \\
2\end{array}$ \\
\hline Zymosan & $\begin{array}{l}10^{5} \\
10^{4}\end{array}$ & $\begin{array}{l}4 \\
1\end{array}$ & $\begin{array}{l}2 \\
0\end{array}$ & $\begin{array}{l}1 \\
0\end{array}$ & $\begin{array}{l}0 \\
0\end{array}$ & $\begin{array}{l}1 \\
1\end{array}$ & $\begin{array}{l}4 \\
1\end{array}$ \\
\hline None & $\begin{array}{l}10^{5} \\
10^{4}\end{array}$ & $\begin{array}{l}2 \\
\mathbf{0}\end{array}$ & $\begin{array}{l}0 \\
0\end{array}$ & $\begin{array}{l}0 \\
0\end{array}$ & $\begin{array}{l}0 \\
0\end{array}$ & $\begin{array}{l}2 \\
0\end{array}$ & $\begin{array}{l}2 \\
0\end{array}$ \\
\hline
\end{tabular}

* Six mice in each group.

$\dagger$ ND indicates sample not suitable for examination.

‡ Colloidal carbon. Results for $\mathrm{ThO}_{2}$ treatment were similar. 
contribution made by the kidney lesions was difficult to assess and conclusive evidence of renal failure was absent. The failure to detect gross abnormalities in urine composition or blood-urea concentration soon after the onset of signs of disease suggested that in spite of the histological and mycological evidence renal function was not seriously disturbed.

These results show some differences from those reported by Smith and Jones (1973). These authors concluded that renal failure was probably the major factor in causing the death of mice with acute Absidia infection, but they did not exclude the possible contributory effects of cerebral infection. Chronic renal lesions of the type described by Smith and Jones (1973) were rarely observed in the present study, even in mice inoculated up to 90 days before necropsy.

These differences in results were probably not related to differences in the strains of $A$. ramosa, as all of our strains produced a similar disease picture irrespective of source. The age of the mice at the time of inoculation may have been more significant. Smith and Jones (1973) inoculated their animals at 5 weeks of age. According to our studies, mice are already showing increased resistance to $A$. ramosa infection by this age and this could modify the nature of the disease.

The effects of age might also explain the results of Symeonidis and Emmons (1955), who observed subcutaneous lesions in mice receiving Absidia spores by this route, although mice inoculated intraperitoneally did not develop disease.

The nature of the dose response in mice inoculated by the intravenous route suggested that disease resulted from the fortuitous penetration of a small number of spores into the central nervous system. The results of direct intracerebral inoculation confirmed this and showed that very small numbers, possibly even single spores, could suffice to establish lethal infection. The considerable difference between the number of spores required to produce disease when inoculated directly into the brain and the number required when inoculated intravenously suggested that a relatively efficient defensive system existed in connexion with the circulatory system but that this did not extend to the central nervous system. The results of cultural and microscopic examination confirmed the observation by Smith and Jones (1973) that most $A$. ramosa spores injected were taken up in the liver and spleen but did not germinate in these organs. It also seemed that few spores were retained by the lungs and those that were did not germinate.

The localisation of actively growing $A$. ramosa in the kidney and brain requires explanation. These tissues perhaps contain specific factors capable of stimulating the in-vivo growth of $A$. ramosa in a manner similar to that produced by extracts of bovine placenta and other tissues (Corbel and Eades, 1973; Eades and Corbel, 1973). However, it is also possible, and perhaps more likely, that the efficiency of the local defence mechanisms of these organs may be more limited than those of other tissues.

Thus, in the case of the kidney, the activity of phagocytic cells may be depressed by hypertonic conditions (Chernew and Braude, 1962) and complement may be inactivated by the high concentrations of ammonium ion in the 


\section{Plate XLVIII}

FIG. 3.-Section of mouse brain showing a mucoraceous hypha stained with haematoxylin. No cellular reaction to the fungus. The animal had been inoculated intravenously 4 days before with $5 \times 10^{6}$ viable spores of $A$. ramosa. HE. $\times 250$.

FIG. 4.-Section of mouse brain showing PAS-positive non-septate fungal hypha of typical mucoraceous type. The animal was inoculated intravenously 5 days previously with $5 \times 10^{6}$ viable spores from $A$. ramosa. PAS-light green. $\times 250$.

Fig. 5.-Fungal mycelium released by digestion in $\mathrm{KOH}$ of the brain of a mouse dying 4 days after intravenous inoculation of $5 \times 10^{7}$ spores from $A$. ramosa. The hyphae are of typical mucoraceous type being non-septate, relatively long, of uniform thickness and with infrequent branching. Interference phase-contrast. $\times 190$. 


\section{EXPERIMENTAL PHYCOMYCOSIS}
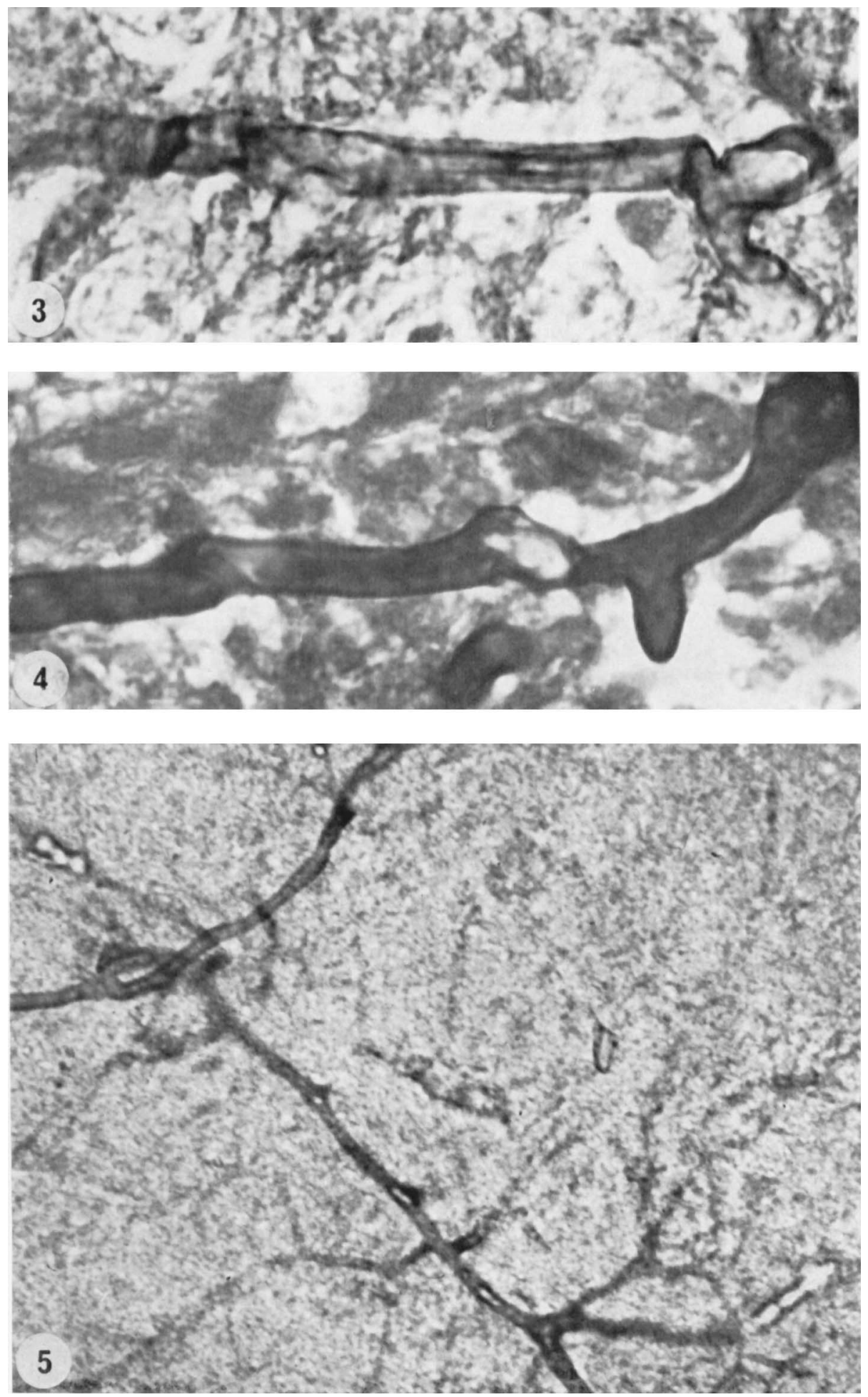


\section{EXPERIMENTAL PHYCOMYCOSIS}

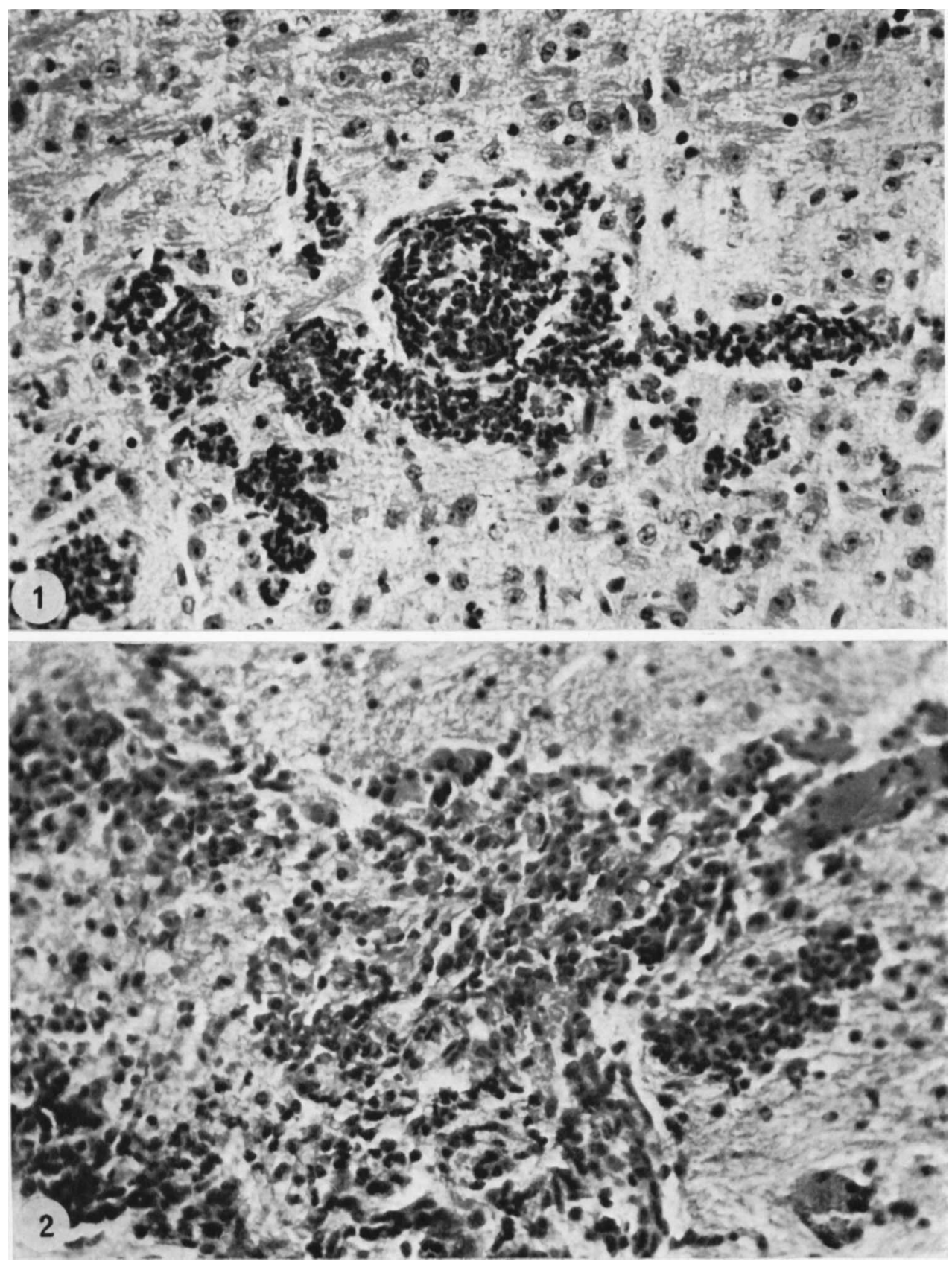

FIG. 1.-Section through the right cerebral hemisphere of a mouse dying 4 days after intravenous injection of $5 \times 10^{7}$ viable spores from Absidia ramosa. A group of lesions consisting of focal accumulations of predominantly mononuclear cells surrounding developing fungal hyphae is visible near the centre of the field. Haematoxylin and eosin (HE). $\times 60$.

Fig. 2.-Part of a lesion similar to those shown in fig. 1; note the predominantly mononuclear character of the cellular infiltrate. HE. $\times 150$. 


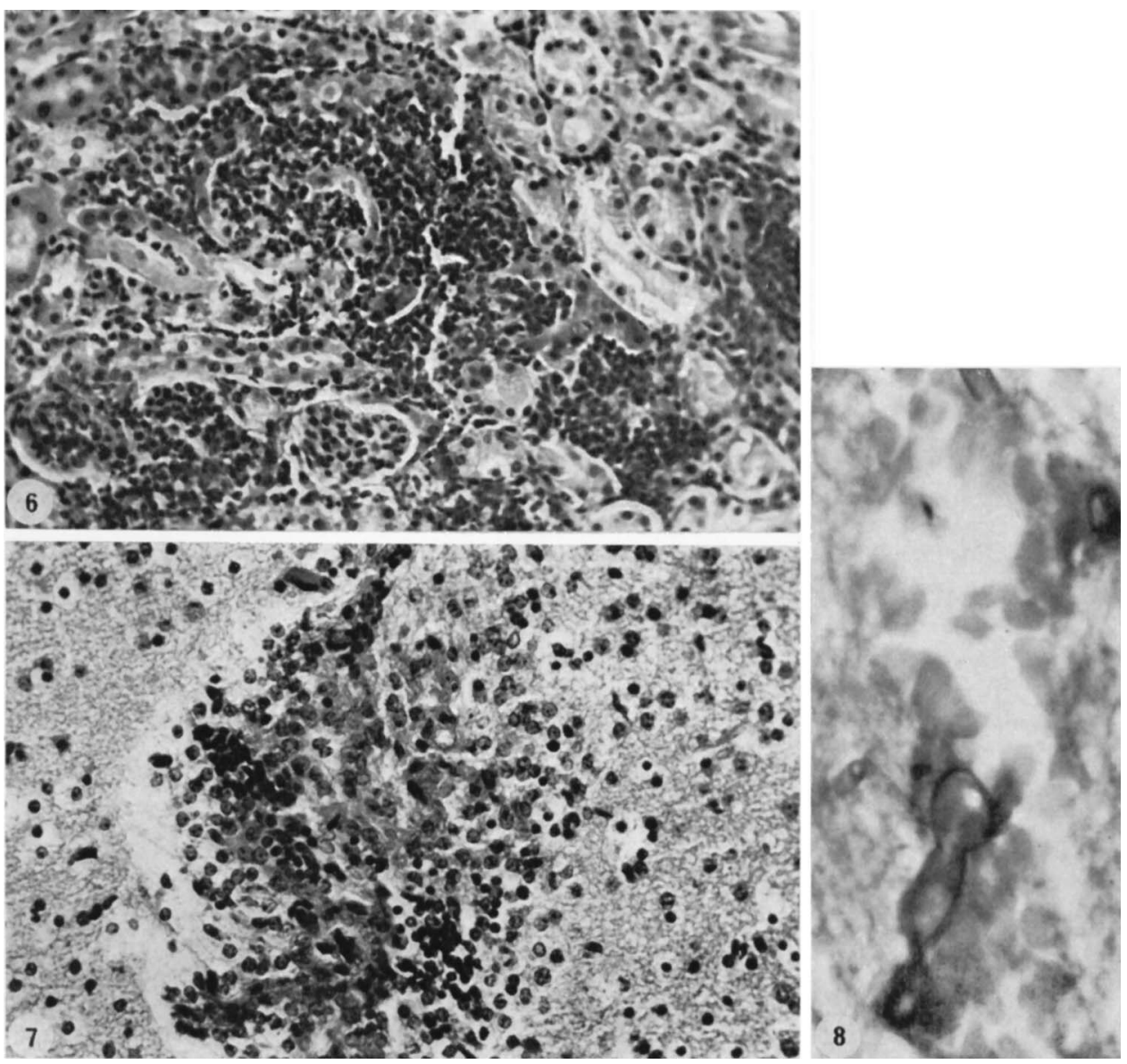

FIG. 6.-Acute lesion produced by $A$. ramosa adjacent to pelvis of a kidney of a mouse dying 6 days after intravenous inoculation of $5 \times 10^{6}$ viable spores. The tissue invaded by fungal mycelium is extensively infiltrated by inflammatory cells comprising mainly histiocytes and neutrophils. HE. $\times 100$.

FIG. 7.-Part of a lesion resulting from direct intracerebral inoculation of spores from $A$. ramosa 3 days before. An area of extensive tissue damage heavily infiltrated by mononuclear cells is apparent. HE. $\times 100$.

FIG. 8.--Section of brain from mouse dying 5 days after intravenous inoculation of spores from A. ramosa. PAS-positive hypha has been sectioned obliquely and appears to penetrate the wall of the blood vessel. PAS-light green. $\times 400$. 
medulla (Beeson and Rowley, 1959). In the central nervous system, the bloodbrain barrier may restrict access of antibodies and other antimicrobial serum factors present in the blood. Also, microglial cells may be less effective in suppressing the germination of fungal spores than are phagocytic cells outside the central nervous system. Differences in the ability of various mononuclear phagocytic populations to inactivate fungal spores were suggested by the observation, in the present study and that of Smith and Jones (1973), of the more rapid elimination of $A$. ramosa spores from the lungs than from other organs. Evidence for the brain as an immunologically restricted site has also been presented by Medawar (1948).

The lower concentration of cationic proteins in brain than in other tissues may contribute to the localisation of Cryptococcus neoformans in this organ (Gadebusch and Johnson, 1966); this factor might also influence the localisation of the other types of opportunistic fungi, including phycomycetes.

The effects of immunosuppressive agents on the development of $A$. ramosa infection tended to confirm the role of natural immune mechanisms in restricting fungal growth in various tissues. The lack of effect of azathioprine, ALS and cyclophosphamide suggested that natural resistance to the fungus was not dependent upon thymus-dependent (T) or thymus-independent (B) lymphocytic function. The effect of zymosan and aggregated $\gamma$-globulin in increasing susceptibility suggested that serum complement and possibly properdin might play a significant part in natural resistance to $A$. ramosa. Zymosan inactivates the $\mathrm{C}_{3}$ component of complement in the presence of properdin at $37^{\circ} \mathrm{C}$ (Pillemer $e t$ al., 1954, 1956). Removal of complement and properdin would markedly deplete the non-specific antimicrobial activity of serum. Furthermore, complement promotes phagocytosis by both mononuclear and polymorphonuclear phagocytes and its removal from the circulation would be expected to reduce phagocytic activity. However, zymosan treatment also reduced the numbers of circulating neutrophils, probably by causing accumulation at the injection site and this effect may have been significant.

This mechanism of $\mathrm{Fe}(\mathrm{II})$ ions in increasing susceptibility to phycomycosis is more obscure. Iron has been shown to exacerbate a number of microbial infections (Weinberg, 1966) and its actions on immune processes are complex (Glynn, 1972). Thus, its influence on phycomycotic infection may have resulted from direct stimulation of fungal growth, although evidence for this was lacking. It may also have been due to saturation of serum transferrin inhibiting its antimicrobial action (Fletcher, 1971), to inhibition of the C9 component of complement (Hadding and Müller-Eberhard, 1967) or perhaps to inhibition of the internal antimicrobial proteins of phagocytes (Gladstone and Walton, 1970).

The marked increase in susceptibility to infection and the disseminated hyphal growth promoted by cortisone acetate was consistent with depression of the activity of phagocytic cells. Although corticosteroids have a complex action on the immune system, the failure of immunosuppressive agents specifically affecting lymphocyte function to increase susceptibility, vide supra, suggested that cortisone acetate did not owe its activity to its effects on these cells. 
Although the activity of cortisone may have resulted from its metabolic glucocorticoid effects, a direct effect on phagocytic cells seems more probable. Cortico-steroids interfere with phagocyte function by stabilising the lysosomal membranes, thus preventing destruction of microorganisms within phagosomes (Weissmann, 1964; Allison, 1968). They have also been shown to interfere with other aspects of phagocyte activity (Chretien and Garagusi, 1971; Cooper, de Chatelet and McCall, 1972). In their recent study of experimental Rhizopus infection in primates, Baker and Linares (1974) also concluded that corticosteroids promoted phycomycotic infection as a result of their immunosuppressive activity. The importance of phagocytes in natural resistance to phycomycosis was also suggested by the increased susceptibility to infection of animals subjected to reticuloendothelial blockade with colloidal carbon or thorium dioxide. In conclusion, it would seem that natural resistance to $A$. ramosa in mice is largely determined by the action of phagocytes, probably acting in conjunction with complement and other non-specific serum factors.

\section{SUMMARY}

Various factors influencing the susceptibility of $\mathrm{C} 3 \mathrm{H}$ mice to lethal infection by the phycomycete Absidia ramosa were examined. Mice 19-21 days old were exposed to graded doses of $A$. ramosa spores by various routes. After intravenous inoculation with doses in excess of $10^{3}$ viable units, a variable proportion of mice developed lethal phycomycosis of the central nervous system within 2-8 days. The proportion of mice affected was related to the inoculum size, doses of $5 \times 10^{7}$ spores producing lethal infection in $90-100 \%$ of the mice. The disease was characterised by signs of involvement of the central nervous system appearing 8-12 $\mathrm{h}$ before death. At necropsy, fungal hyphae, frequently surrounded by infiltrations of mononuclear cells, could be demonstrated in the brain. Lesions were also often present in the kidneys; in other organs they were rare, but the presence of viable fungal spores could be detected by cultural procedures. Subcutaneous inoculation of $A$. ramosa spores did not produce lethal infection but intraperitoneal inoculation occasionally did so. Direct intracerebral inoculation invariably produced lethal infection even with very small doses of spores. The clinical and histopathological features of the disease were almost identical with those resulting from intravenous inoculation.

Pre-inoculation treatment with azathioprine, cyclophosphamide and antithymocyte serum did not increase susceptibility. Susceptibility was increased by injections of zymosan, aggregated $\gamma$-globulin, cortisone acetate and $\mathrm{Fe}$ (II) salts and by reticuloendothelial blockade. These treatments increased the proportion of mice developing lethal phycomycosis of the central nervous system, and in the case of cortisone acetate, also promoted disseminated infection.

It was concluded that the natural resistance of mice to $A$. ramosa infection was probably dependent upon the activity of phagocytic cells, possibly acting in conjunction with complement and other non-specific serum factors. 
The authors wish to thank Mr A. R. W. Castleman for excellent technical assistance, Mrs C. A. Day for the haematological examinations, Mr R. Sayer for the photographs and Dr J. T. Done and the staff of the Pathology Department for their co-operation in preparing the histological sections.

\section{REFERENCES}

Ainsworth, G. C. AND Austwick, P. K. C. 1959. Fungal diseases of animals, Farnham Royal.

Allison, A. C. 1968 . The role of lysosomes in the action of drugs and hormones. $A d v$. Chemother., 3, 253.

BAKER, R. D. 1971. The pathologic anatomy of mycoses. In Handbuch der speziellen pathologischen Anatomie und Histologie, edited by E. Uehlinger, Berlin, Heidelberg and New York, vol. 5, part 3.

BAKER, R. D. AND Linares, G. 1974. Prednisolone-induced mucormycosis in rhesus monkeys. Sabouraudia, 12, 75.

Beeson, P. B. AND Rowley, D. 1959. The anticomplementary effect of kidney tissue: its association with ammonia production. J. exp. Med., 110, 685.

Chernew, I. AND Braude, A. I. 1962. Depression of phagocytosis by solutes in concentrations found in the kidney and urine. J. clin. Invest., 41, 1945.

Chretien, J. H. AND Garagusi, V. F. 1971. Suppressed reduction of nitroblue tetrazolium by polymorphonuclear neutrophils from patients receiving steroids. Experientia, 27, 1343.

COOPER, M. R., DE Chatelet, L. R. AND MCCALl, C. E. 1972. The in vitro effect of steroids on polymorphonuclear leukocyte metabolism. Proc. Soc. exp. Biol. Med., 141, 986.

CORBEL, M. J. AND EADES, S. M. 1973. The effect of soluble extracts of bovine placenta on the growth of fungi implicated in bovine mycotic abortion. Br. vet. J., 129, lxxv.

Culling, C. F. A. 1974. In Handbook of histopathological and histochemical techniques, 3rd ed., London, p. 457.

EADES, S. M. AND CORBEL, M. J. 1973. The effect of soluble bovine placental extracts on the in vitro growth of fungi implicated in bovine mycotic abortion. Proc. Soc. gen. Microbiol., 1, 27.

Emmons, C. W., Binford, C. H. AND Utz, J. P. 1970. In Medical mycology, 2nd ed., Philadelphia, p. 490.

FLETCHER, J. 1971. The effect of iron and transferrin on the killing of Escherichia coli in fresh serum. Immunology, $20,493$.

GADEBUSCH, H. H. AND Johnson, A. G. 1966. Natural host resistance to infection with Cryptococcus neoformans. IV. The effect of some cationic proteins on the experimental disease. J. infect. Dis., 116, 551.

Gladstone, G. P. AND Walton, E. 1970. Effect of iron on the bactericidal proteins from rabbit polymorphonuclear leucocytes. Nature, Lond., 227, 849.

GlynN, A. A. 1972. Bacterial factors inhibiting host defence mechanisms. In Microbial pathogenity in man and animals, edited by $\mathbf{H}$. Smith and J. H. Pearce, Society for General Microbiology Symposium no. 22, Cambridge, p. 75.

HAdDING, U. AND MülleR-EberhaRd, H. J. 1967. Complement: substitution of the terminal component in immune haemolysin by 1,10-phenanthroline. Science, N.Y., 157, 442.

HenRY, R. J. 1964. In Clinical chemistry, New York, p. 226.

MEDAWAR, P. B. 1948. Immunity to homologous grafted skin. III. The fate of skin homografts transplanted to brain, to subcutaneous tissue and to the anterior chamber of the eye. Br.J.exp.Path., 29, 58.

Pillemer, L., Blum, L., Lepow, I. H., Ross, O. A., Todd, E. W. and Wardlaw, A. C. 1954. The properdin system and immunity. I. Demonstration and isolation of a new serum protein, properdin, and its role in immune phenomena. Science, N.Y., 120, 279.

Pillemer, L., Blum, L., Lepow, I. H., Wurz, L. AND Todd, E. W. 1956. The properdin system and immunity . III. The zymosan assay of properdin. J. exp. Med., 103, 1. 
SMTth, J. M. B. AND Jones, R. H. 1973. Localisation and fate of Absidia ramosa spores after intravenous inoculation of mice. J. comp. Path., 83, 49.

Symeonidis, A. AND Emmons, C. W. 1955. Granulomatous growth induced in mice by Absidia corymbifera. Archs Path., 60, 251.

TIMONEY, J. 1970. The effect of decomplementation on Erysipelothrix rhusiopathiae infection in the mouse. Immunology, 19, 561.

WeInBERG, E. D. 1966. Roles of metallic ions in host-parasite interactions. Bact. Rev., 30, 136.

Weissmann, G. 1964. Lysosomes. Blood, 24, 594. 